\title{
Biró AnnAmária*
}

\section{IDENTITÁSELEMEK EGY 19. SZÁZADI ÉLETPÁLYÁBAN: GOTTFRIED FELDINGER/FÖLDÉNYI FRIGYES}

\author{
Kulcsszavak: kétnyelvüség, egyéni és nemzeti identitás, asszimiláció, reformkori folyóiratok
}

Gottfried Feldinger életpályáját tekinthetnénk egy 19. századi művelt, peregrinált német anyanyelvű ifjú tipikus életpályájának, amelyben elkerülhetetlen, de legalábbis előre látható az asszimiláció, a magyar nemzethez való tartozás igénye és megvalósítása. Fontosnak tartom mégis megvizsgálni egy ilyen - viszonylag nehezen rekonstruálható - életút tanulságait, mivel a kiegyezés előtti, azaz a kevésbé erőszakos magyarosítás kérdésével többnyire átfogó tanulmányok vagy kötetek foglalkoznak, amelyben természetszerúleg figyelmen kívül maradnak az egyéni motivációk, ezért kizárólag általános tendenciaként a domináns nemzetiséghez való tartozás igényével magyarázzák az elmagyarosodást. ${ }^{1} \mathrm{Az}$ egyéni életutak vizsgálatában is hangsúlyosabbá válik annak az időszaknak az elemzése, amelyben az integrálódó egyén az általa választott nyelven, nem pedig az anyanyelvén alkot. ${ }^{2}$ Gottfried Feldinger esetében azonban sokkal jobban dokumentálható életének az a korszaka, amikor többnyire német nyelven alkot, német nyelvü közönséghez szól és német nyelven közvetíti a 48-as forradalom előtti és utáni magyar liberális törekvéseket. Nevének és írásainak magyar nyelvưvé válása után mintha eltűnne a köztudatból, sikeresnek csak akkor mondható, amikor nem a választott nyelvén alkot. Dolgozatom két részből áll: az első részben a magánéletet és azokat a motivációkat vizsgálom, amelyek miatt a temesvári német ifjú magyar hazafivá válik, aki 1861-ben

* Biró Annamária, dr. (1980), irodalomtörténész, az EME kutatója és a PKE adjunktusa. Fő kutatási területei: 18-19. századi irodalom-, értelmiség- és kultúrtörténet, magyar-német kapcsolatok, kapcsolathálók. Kiadta Aranka György történeti munkáját: Aranka György Erdély-története, Erdélyi Múzeum-Egyesület, Kolozsvár, 2010, (ETF 264), doktori disszertációja pedig egy szász-magyarnémet vita értelmezése: Nemzetek Erdélyben. August Ludwig Schlözer és Aranka György vitája, Erdélyi Múzeum-Egyesület, Kolozsvár, 2011 (ETF 272).

1 A témához kapcsolódó fontosabb szakirodalom: Karády Viktor-Kozma István: Név és nemzet. Családnév-változtatás, névpolitika és nemzetiségi eröviszonyok Magyarországon a feudalizmustól a kommunizmusig. Osiris, Bp., 2002; SPIRA György: A nemzetiségi kérdés a negyvennyolcas forradalom Magyarországán. Kossuth, Bp., 1980; KemÉNy G. Gábor: Társadalom és nemzetiség a szabadságharc hadi lapjaiban. Bp., 1957; Csetri Elek-IMreH István: Erdély változó társadalma 1767-1821. Bukarest 1980; DєÁк Ágnes: „Nemzeti egyenjogúsítás”. Kormányzati nemzetiségpolitika Magyarországon 1849-1860. Bp., 2000, PÁL Judit: Unió vagy „unificáltatás”? Erdély uniója és a királyi biztos müködése 1867-1872. EME, Kolozsvár, 2010. Az elmagyarosodás okait kisebb közösségben vizsgálta: BindorfFer Györgyi: „wir Schwaben waren immer gute Ungarn“. Bp., 2005.

2 Ez a tendencia persze azzal is magyarázható, hogy a későbbiekben valamilyen alkotói pályát befutó nemzetiségváltók többnyire fiatal korban, tevékeny periódusok kezdetén térnek át a domináns nemzetiség nyelvére. Egy ilyen életpálya példaértékủ vizsgálatát 1. DÁvidHázi Péter: Egy nemzeti tudomány születése. Toldy Ferenc és a magyar irodalomtörténet. Bp., 2004. 
hivatalosan is kéri nevének Földényire változtatását. A dolgozat második fele foglalkozik azokkal a többnyire német nyelvű írásaival, amelyek az 1848 előtti és utáni reformtörekvésekhez kapcsolják.

Feldinger neve nem ismeretlen sem a magyar, sem a bánsági német kultúrával, irodalommal foglalkozók körében ${ }^{3}$, a kutatást mégis a bizonytalan adatokkal teli életút rekonstruálásával kellett kezdeni ahhoz, hogy identitáskomponenseit, a német nemzetiségének vagy az alakuló magyar nemzethez való tartozásának specifikus elemeit megismerhessük. Temesvári evangélikus német kereskedőcsaládba született, és bár gyerekkoráról, tanulmányairól keveset tudunk, annyi mégis világos, hogy látási problémái ellenére ${ }^{4}$ a tipikus német evangélikusok pályáját kezdi el: németországi egyetemeken tanul, jogi és bölcseleti diplomát szerez. ${ }^{5}$ Ennek a ténynek nem önmagában van jelentősége, hanem azért, mert a korszak kutatói gyakran hangsúlyozzák, hogy II. József uralkodásától kezdve éppen azok a protestáns diákok váltak állampatriótákká, akik a német egyetemeken a legkorszerúbb ismereteket szerezték, és tisztában voltak az állam és alattvaló filozófiailag is megalapozott viszonyával. ${ }^{6}$ Ebből azonban nem következik automatikusan, hogy ez a csoport a reformkorban a magyar újító mozgalmakhoz és a későbbi autonómiatörekvésekhez fog kapcsolódni, hiszen például ilyen szempontból az erdélyi szászok is ehhez a csoporthoz tartoztak, mégis teljes mértékben elzárkóztak a magyar törekvésektől. Ezért is tartom elfogadhatatlannak Pukánszky Béla azon tételét, miszerint a németek a reformkorban észrevették a nemzet magasabbrendűségét az államénál, így lett belőlük jó patriótából tüzes hazafi. ${ }^{7}$ Egyrészt a németeket semmiképpen sem lehet homogén csoportként kezelni, másrészt Feldinger életútja és írásai azt bizonyítják, hogy a liberális törekvések között nem vette észre a nemzetiségi törekvéseket, számára a nemzet nem nyelvi alapú, hanem a felvilágosodás eszmeköréből táplálkozó állami elkülönülést jelentett. A

3 Az életpálya rekonstruálásához az alábbi szövegeket használtam fel: Szinnyei József: Magyar irók élete és munkái Földényi-szócikkét: http://www.mek.oszk.hu/03600/03630/html/ (utolsó hozzáférés: 2013. 01. 06.); Dieter Kessler: Die deutschen Literaturen Siebenbürgens, des Banates und des Buchenlandes. Von der Revolution bis zum Ende des Ersten Weltkriegs (1848-1918). Böhlau Verlag, Köln, Weimar, Wien. 1997. (Studia Transylvanica 23); Heinz StĂnescu: Gottfried Feldinger, der 1851er Temesvarer Biograph Petöfis. Lenau-Forum: Vierteljahresschrift für vergleichende Literaturforschung. 1972/3-4. 20-30; Walter ENGEL: Deutsche Literatur im Banat (1830-1939). Heidelberg. 1982.; Fавó Irma: Az „Euphrosine“ negyvennyolc és Petöfi. Magyar Könyvszemle. 1974/1-2. 149-155; Izsák László: Petöfi első biográfusa és a temesvári Euphrosine. Korunk. 1973/1. 141-145; Mária Rózsa: Die Aufnabme der ungarischen Revolution und des Freiheitskampfes in der siebenbürgischen deutschsprachigen Presse 1848-1849 = Österreichisch-Siebenbürgische Kulturbeiträge: ein Sammelband der Österreich-Bibliothek Cluj-Napoca-Klausenburg-Kolozsvár, Hg. Rudolf GräF und Ute Michailowitsch. Presa Universitara Clujeana. 2008.125-137.

4 Nem sokkal születése után megvakul bal szemére és a jobb szemének is oly gyenge a látása, hogy csak napi néhány percet használhatott olvasásra. Idősebb korára csaknem teljesen megvakul, olvasni és írni egyáltalán nem tud.

5 1846. aug. 23-án a Der Ungar címú pesti lapban jelenteti meg peregrinációs emlékeit: Halle, Jena, Weimar, Erfurt, Gotha, Eisenach és Lipcse bemutatására helyezi a hangsúlyt. G. Feldinger: Bestreute Blätter aus meinem Reise-Tagebuche. Der Ungar. 1846/197.

6 Ld. H. Balázs Éva: Berzeviczy Gergely, a reformpolitikus. Bp., 1967.; Benda Kálmán: Emberbarát vagy hazafi? Tanulmányok a felvilágosodás korának magyarországi történetéból. Gondolat. Bp., 1978.; S. Varga Pál: A nemzeti költészet csarnokai. Balassi, Bp., 2005.

7 PuкÁnsz кy Béla: „Patrióta” és „,hazafi”. Fejezet a magyarországi német irodalom történetéböl. Bp., 1933. 
nyelvi alapú nemzeti elkülönüléssel és a nemzetiségi mozgalmakkal foglalkozók gyakran figyelmen kívül hagyják a felekezeti komponenst az identitáselemek vizsgálatában. Feldinger esetében azonban megkerülhetetlen az a tény, hogy a későbbi evangélikus püspök, Sárkány Sámuel volt a nevelője, és ő az, aki a pesti evangélikus családokban keres és talál neki feleséget Kánya Emília személyében, aki a magyar nyelvű szakirodalomban azért híres, mert késôbb, válásuk után, ő lesz az első női újságszerkesztő. ${ }^{8}$ A családalapítás tehát erőteljesen felekezeti meggondolások alapján történik, kérdéses csupán az lehet, hogy miért nem a helyi, temesvári közösségben keres feleséget magának. ${ }^{9}$ Kánya Emília memoárjából tudjuk, ${ }^{10}$ hogy 1847 -es Temesvárra költözésük után a családban kizárólag németül beszéltek annak ellenére, hogy az idősebb Feldinger viszonylag jól tudott magyarul. ${ }^{11}$ Irodalmi teljesítményük alapján nyilván nem hasonlítható össze Feldinger/Földényi és Schedel/Toldy Ferenc, a magyar irodalomtörténet-írás megteremtője, ám az identitásstruktúrák mégis összevethetők. Toldyt a magyarul nem beszélő budai német szülők terelik a magyar nyelvűség irányába, ${ }^{12}$ és valószínűsíthető, hogy Feldinger esetében is arról lehet szó, hogy a kereskedő apa a testi fogyatékossággal rendelkező fiút hivatalnoki életpályára szánja, amelynek gyakorlásában elkerülhetetlen a magyar nyelv ismerete. Feltűnő, hogy Feldinger 1848-ban kezdi el írásait Földényi szignóval ellátni, ám ez csak részben magyarázható a forradalmi törekvésekkel való azonosulásával. Felesége révén Pesten abba a liberális fiatal értelmiségiekbőlálló körbe kerül, akik a Junges Deutschland költőivel és újságíróival értenek egyet, azaz egy polgári demokrácia megteremtésén fáradoz$n^{13}{ }^{13}$ 1848-49-ben azokban a radikális ellenzéki lapokban publikál, amelyek német nyelven jelennek ugyan meg (Der Ungar, Der vierzehnte April), ám szerkesztői és szerzői többnyire német anyanyelvű protestánsok és zsidók. Ezek a lapok általában még akkor sem veszik észre a 48-as forradalom és szabadságharc nemzetiségi problémáit, amikor azok egyre fenyegetőbbé válnak. Ennek a körnek az asszimilációs tendenciáit támasztják alá azok a kutatások is, amelyek arra fókuszálnak, hogy a reformkorban a névváltoztatás egyre inkább demonstratívvá válik, és a magyar törekvések teljes körű átvételét jelentik. Innen nézve Feldinger némiképp megkésve reagál, hiszen ekkoriban még felváltva használja a Feldinger és Földényi szerzői nevet, hivatalos névváltoztatást pedig csak 1861-ben kér, amikor ez a tendencia csitul. ${ }^{14} 1848-$

8 Kánya Emília életútjához és munkásságához 1. Töвöк Zsuzsa: Kánya Emília írói és szerkesztöi pályája. Irodalomtörténet. 2011/4. 475-489.

9 Testi fogyatékosságai mellett későbbi, kicsapongó életmódját ismerve feltételezhetjük, hogy már fiatal korában voltak erre utaló jelek, így nem volt vonzó a helybéli családok számára.

10 Kánya Emília: Réges-régi időkröl. Egy 19. századi irónó emlékiratai. s. a. r. FÁB RI Anna és Kiss Bori. Kortárs Kiadó. 1998.

11 KÁNYa Emília: i. m. 85.

12 ld. Dávidházi Péter: $i . m$. 58-59.

13 A Junges Deutschlandhoz 1. Helmut Koopman: Das Junge Deutschland. Eine Einführung. Wiss. Buchgesellschaft. Darmstadt. 1993; Wolfgang Bunzel, Peter Stein, Florian Vassen (Hg.): Romantik und Vormärz. Zur Archäologie literarischer Kommunikation in der ersten Hälfte des 19. Jabrhunderts. Aisthesis. Bielefeld. 2003.

14 Természetesen azt is figyelembe kell venni, hogy mivel 1848-1849-ben elmulasztotta a hivatalos névváltoztatást kérni, 1850 után már nehezen állt volna módjában ezt megtenni. 1849. november 27-én ugyanis megtiltják a névmagyarosításokat. A rendeletet 1 . Századunk névouáltoztatásai. Helytartósági és miniszteri engedélylyel megváltoztatott nevek gyújteménye 1800-1893. Eredeti okmányok alapján összeállította a Magyar Heraldikai és Genealógiai Társaság egyik igazgatóválasztmányi 
49-ben 684 névmagyarosítást hagynak jóvá, 1850-1860 között 17-et, 1861-1862 között pedig 545 -öt. ${ }^{15} \mathrm{Ha}$ a névváltoztatók felekezeti megoszlását nézzük, akkor újra azt látjuk, hogy a kérelmezők többsége zsidó, evangélikus és katolikus, a többi felekezet alulreprezentált. ${ }^{16}$ Feldinger esetében érthető a késői reakció: 1848-49-ben eleinte Pesten, később Temesváron írja forradalmi tárcáit, ahonnan ősszel családostól újra menekülnie kell, ekkor Pest környékére, a Pilisbe tér vissza. Nagyhatalmú apjának köszönhető, hogy békében távozni hagyják. Ugyancsak felesége emlékiratából idézek: „Magyar érzésűnek lenni ugyanaz volt, mint forradalmárnak lenni. Egymást érték az elfogatások. Apósomat egypár rác vagy illir ismerős figyelmeztette: vigyázzon a fiára, a családjára, ne igen mutassa magát közhelyeken. Mert most ők itt az urak, nem a magyarok. Jól tudják ők, hogy fia Pesten véres cikkeket írt a kamarilla és a bécsi kormány ellen, és csakis apja ismert nyugodt, higgadt viselkedésének és egypár magasabb rangú katonatiszttel való összeköttetésének köszönheti, hogy még eddig nyugodtan hagyták az »úrfit «”. ${ }^{17}$ A szabadságharc bukása után visszatérnek, német nyelvü lapot adnak ki, a magánéleti problémák azonban 1860-ban újra távozásra kényszerítik őket. Budapesten felesége elválik tőle, Feldinger újranősül és a történész Wenzel Gusztáv húgát, Vilmát veszi feleségül. Ekkortól kezdve keveset tudunk róla, Szinnyei szerint a miniszterelnöki sajtóhivatalban dolgozott. ${ }^{18}$ Bár a legtöbb szakirodalmi tétel szerint 1903-ban halt meg, a Vasárnapi Újság már 1900 októberében hírt ad elhalálozásáról. ${ }^{19}$ A tudósító szerint ismert alakja a budapesti életnek, csaknem teljesen megvakulva olvastatja fel magának a lapokat, majd fóleg hangversenykritikákat diktál hordárainak, melyeket külföldi lapokban publikál. Feldinger magánélete magyarázatot adhat magyarrá válására: abban az általánosan jellemző komponensek (evangélikus neveltetés, Junges Deutschland republikánus mozgalommal való szimpátia) és a magánéleti események (magyar feleség, a magyar liberális körökbe való belépés, Petőfi Sándor személyes ismerőse, Temesvárról való többszöri menekülés) kiegyenlítik egymást és magyarázatot adnak az asszimilációra.

Az írói nyelvhasználat, a német-, illetve magyarnyelvűség, a magyar radikális eszmék német nyelven való tolmácsolása azonban újabb problémákat vet föl. Eddigi adataink szerint Feldinger 1843-ban kezd publikálni a Temesvarer Wochenblatt címü lapban. 1846-ig többnyire német nyelvű verseket közöl, amelyek nem sok esztétikai értéket hordoznak, főleg a Sturm und Drang természeti képeit és a kora romantika érzelmességét tükrözik. Munkásságának ezzel a részével nem foglalkozom, jelentősebbnek érzem a 48-49-es szövegeit, valamint az 1851-ben Temesváron kiadott Euphrosine című lapját. A 19. század elejéig nem merült fel problémaként a két, esetenként több nyelven alkotó szerzők jelenléte az akkoriban dominánsan többnyelvű kultúrákban. Feldinger azonban akkor kezd el magyar és német nyelvű szövegeket párhuzamosan közölni, amikor ez már a német és a magyar kultúrában is problémás.

tagja [Szentiványi Zoltán]. Bp., 1895.13-14. A tiltó rendeletet 1860-ban oldották fel, tehát ilyen szempontból Feldinger akkor lépett, amikor erre újra lehetősége volt.

15 KarÁdy Viktor-Kozma István: i. m. 28-29.

16 KarÁdy Viktor-Kozma István: i. m. 41.

17 KÁnya Emília: i.m. 91.

18 Szinnyei József: Magyar irók élete és munkái Földényi-szócikkét: http://www.mek.oszk. hu/03600/03630/html/ (utolsó hozzáférés: 2013. 01. 06.)

19 Vasárnapi újság. 1900. október 7.666. 
1813-ban Friedrich Schleiermacher is elutasítja a két nyelven való alkotás lehetőségét ${ }^{20}$, a már említett Toldy Ferencet, aki kortársnak tekinthető, szintén folyamatosan vádak éri magyar nyelvű szövegei miatt ${ }^{21}$. Ekkor már lecsengett az a Kazinczy és Vörösmartyék között zajló vita is, hogy mennyiben tekinthető egy német nyelven verseket író szerző magyar költőnek (Pyrker-pör $)^{22}$. Feldinger nem volt annyira jelentős, hogy felfigyeltek volna rá mint két nyelven alkotó szerzőre, ezért alkotási stratégiái nem is problematizálódnak a korszakban. Többnyire prózát közöl a Pesti Divatlapban, a Reform címû rövid életű sajtóorgánumban és a Márczius tizenötödike címú forradalmi lapban. Az akkoriban meglehetősen könnyedén és a forradalmi stílust pillanatok alatt elsajátító magyar nyelvű (sok esetben magyar nyelvűvé vált) újságírók mellett azonban Feldinger, ekkoriban inkább már Földényi, nem tud kitűnni, ezzel magyarázható magyar nyelvű szövegeinek lényegesen kisebb száma. A kétnyelvű szerzők esetében a kortársak és a későbbi szakirodalom is jelentősebbnek tartja a fordítói munkát, elsősorban a szépirodalmi szövegek megismertetését. A magyar törekvések egyik német nyelvü közvetítője a radikális Der Ungar címú divatlap, majd később a forradalom mellé álló újság volt. ${ }^{23}$ Főszerkesztője a zsidó származású Hermann Klein, aki később szintén névmagyarosítást kér, így lesz belőle Kilényi János. ${ }^{24}$ A lap 1848 októberéig megőrizte liberális, a magyar nemzeti törekvéseket közvetítő jellegét. Ennek állandó szerzője volt Feldinger, 1846-tól folyamatosan publikál hol Feldinger, hol Földényi szignóval olyan ismert szerzők mellett, mint Beck Károly, Falk Max/Falk Miksa, Nessbaum/Diósy Márton vagy a Junges Deutschland alkotói. Feldinger saját verseitől most eltekintve egyetlen Eötvös József-fordítását emelném ki, amely 1847-ben jelent meg. ${ }^{25}$ Eötvös József Végrendelet címú versét a Der Ungar címú lap 1847. február 21-i számában olvashatjuk Testament címmel. Feldingerhez nemcsak azért állhatott közel Eötvös verse, mert ugyanazt az érzelmes lírát képviseli, amellyel ő is kísérletezett, hanem mert az elmúlás fölötti bánat mellett a haza és az emberiség sorsa miatti aggódás is megjelenik a sorokban. Eötvös korai politikai nézetei is közel állhattak Feldingerhez, hiszen ő a szabadság és és egyenlőség eszméit a francia forradalom ideológiájából sajátította el, majd

20 Friedrich Schleiermacher: Über die verschiedenen Methoden des Übersetzens, in: Friedrich Schleirmacher's sämmtliche Werke. 3. Abtheilung: Zur Philosophie. Bd. 2. Berlin. 1838. 207-245.

21 DÁvidházi Péter: $i$. m. 115-120.

22 A Pyrker-pör anyaga: Tollharcok. Irodalmi és szinházi viták 1830-1847. S.a.r. Szalai Anna. Budapest. Szépirodalmi Kiadó. 1981. T. ErdéLYI Ilona alaposabban is elemezte a vitát: T. ERdÉLYI Ilona: Egy kései kiengesztelés kisérlete (Nébány megjegyzés a „Pyrker-pör” kapcsán). ItK. 1996/5-6. 630-648.

23 Der Ungar. Zeitschriftliches Organ für ungarische Interessen, für Kunst, Eleganz, Literatur, Theater und Mode. 1848 júliusában az alcím módosul, explicitebben fejezve ki ezáltal a politikai események iránti elközelezettségét: Zeitschriftliches Organ für politische und soziale Interessen. Október 1-jén a lap szerkesztését ZERfFi Gusztáv veszi át, az alcím újra megváltozik: Allgemeine Zeitung für Politik und Belletristik.

24 A reformkori német nyelvú lapokról 1. UGRIN Aranka: Reformkori német nyelvú hírlapok és folyóiratok, in: KóкAY György (szerk.): A magyar sajtó története 1705-1848. Akadémiai, Bp., 1979. 564-569.

25 Eötvös József Végrendelet címú verse a Pesti divatlapban jelent meg 1847. február 21-én. Pesti Divatlap. 1847. első félévi folyam. 232. A későbbi közlések azonban a verset 1848-ra datálják, ráadásul egy versszakot kihagyva közlik. L. Báró Eötvös József összes munkái. Költemények. Színmüvek. Révai Bp., 1903. Ennek nyomán pedig az Arcanum által készített Verstár is a hibás verziót és évszámot adja. L. http://www.mek.oszk.hu/00600/00644/00644.htm (utolsó hozzáférés: 2013. január 20.) 
a forradalom eseményei hatására gondolta tovább. ${ }^{26}$ Bár itt még korai lenne előrevetíteni az 1848-49-es szabadságharc bukása után vallott nézeteit, mégis feltételezhető, hogy a korszak sok politikai gondolkodójához hasonlóan már ekkor is úgy vélte, hogy a nemzeti önértelmezés nyelvi alapúsága vagy a nacionalizmus idővel el fog enyészni, hiszen egy általánosabb érvényủ szabadságfogalomban hitt. A magyar olvasók számára ismertek lehettek Eötvös nézetei, Feldinger azonban elsősorban a német nyelvú közönség számára ír, ezért nem meglepő, hogy a versben csupán jelen lévő jövőbeli szabad haza vízióját, felszólítássá, sürgető igénnyé alakítja: „Dort wo mich begraben,/Wo Ruh' die Seele fand,/Hab ich einst auferstehe,/Sei frei mein Vaterland!“ ${ }^{27}$

A német verzió utolsó versszakában megjelenő emberbarát így összefonódik a jó hazafi képével, amely egyrészt a felvilágosodásra visszautaló dichotómia (emberbarát vagy hazafi28) feloldása, másrészt viszont a zsidó emancipációról is értekező Eötvös ideológiájának, a nemzetiségi ellentétek eltörlésének olyan konkrét megfogalmazása, amely az eredeti versből hiányzik, lévén ott csupán baráti felszólítás a költő gyászolására:

„Das Lied gönnt mir als Dichter,/Wenn ihr am Grabe erscheint,/Und weinet eine Thräne/ Um mich, den Menschenfreund“. ${ }^{29}$

A Der Ungar címú lapnál radikálisabb szellemben írták azt a Temesvárhoz is sokkal inkább kötődő lapot, amelynek a Márczius Tizenötödike mintájára a Vierzehnte April címet adták, azaz a Habsburg-ház trónfosztásának, a Függetlenségi Nyilatkozat kihirdetésének napjára utaltak általa. Főszerkesztője a temesvári származású Heim, később Hazay Ernő, Feldinger korábbi barátja volt, így nem meglepő, hogy Feldinger ebben az igen rövid életű (1849. június 1-tôl július 7-ig jelent meg) lapban lelkesen publikált. A programírás szerint a lap a republikánus eszmék híve: „Die demokratische Republik mit allen ihren Konsequenzen ist das Programm unseres Strebens, ist die Aufgabe unseres Kampfes “. ${ }^{30}$ Kossuth Lajos feltétlen hívei, akit még abban az esetben is követnének, ha az a republikánus eszméket félretéve királylyá koronáztatná magát. Mivel a lap szerzői között leghangsúlyosabban Heim és Feldinger vannak jelen, talán nem túlzunk, ha azt mondjuk, hogy az írásokból levonhatunk olyan általánosabb következtetéseket is, amelyek a magyar szabadságharc oldalára állt nemzetiségekre általánosan jellemzők. Nem csupán arról a szakirodalomban gyakran hangozatott tételrốl van szó, hogy az elvakult Kossuth-hívők és a demokratikus köztársaság hívei nem akartak tudomást venni az 1849-ben már általános problémává érett nemzetiségi ellentétekről, hanem az is eléggé világosan látszik, hogy nem vettek tudomást azokról a csoportokról sem, akik nem feltétlenül a polgári értékekben, hanem a már viszonylag elterjedt Kommunista Kiáltvány egyegy elképzelésében hittek. Előbbire példa Feldinger Zur Charakteristik unseres Kampfes címú

26 Eötvös nemzetiségi kérdésekben elfoglalt álláspontjáról 1. Demeter M. Attila: Eötvös Józsefnemzetiségi nézetei az Uralkodó eszmékben. Magyar kisebbség. 2009/1-2. 38-49.

27 Der Ungar. 1847. feb. 21. Eötvös magyar nyelvű szövege: „A mellyben eltemettek,/Hol szívem megpihen,/S egykor feltámadandok-/A hon szabad legyen"

28 BENDA Kálmán: Emberbarát vagy hazafi? Tanulmányok a felvilágosodás korának magyarországi történetéból. Gondolat Bp., 1978.

29 Der Ungar. Uo. Eötvös: „És sírjatok egy könyet/Barátotok felett:/Dalt érdemelt, mert költő,/ Könyüt, mert szeretett."

30 Der vierzehnte April. Nr. 1. Pest, 1. Juni 1849. „Törekvéseink programja és harcunk tétje a demokratikus köztársaság annak minden következményével.” (ford. B. A.) 
írása, amelyben konkrétan kijelenti, hogy a szerb és horvát megmozdulások a Habsburgok provokációja miatt történtek és téves az az elképzelés, hogy a magyarok bárkit korlátoznának nyelvük vagy vallásuk gyakorlásában: „Gewiß war der erste Krieg gegen die Serben kein Unterdrückungskampf gegen die serbische Nation, denn Ungarns Söhne haben nie zur Unterdrückung eines Volkes aus freiem Antriebe gefochten, und sie werden es auch nie.

Es sollte ohne Zweifel der alte satanische Metternich'sche Plan realisirt werden, die Bewohner Ungarns verschiedener Zunge gegeneinander zu reizen, sie zum Bürgerkrieg zu bewegen, um so nach Vernichtung ihrer besten Kräfte und aller Vehikel der Freiheit die Betrogenen um so sicherer und leichter beherrschen, deutlicher gesagt, knechten zu können“.31

A demokratikus köztársaságtól eltérő elképzelésektől pedig már a programírásban elzárkóznak: „Es ist überflüssig unsere Gesinnung über die neuesten sozialen Auswüchse auszusprechen, doch aus Rücksicht auf die Verdächtigung des Kommunismus, mit der die Monarchisten alles beschmutzen, was die Fahne der Republik trägt, werden wir einige Worte darüber sagen. In Ungarn halten wir die Absicht der Einführung des Kommunismus für noch lächerlicher aus die Furcht vor demselben“.32 A munkásokkal ebben az időben leginkább Táncsics Mihály foglalkozik, aki Munkások Újságja címmel szerkeszt lapot. ${ }^{33}$ Hasonlóan a Vierzehnte Aprithez a Temesvárer (!) Wocheblatt sem ismeri fel annak veszélyét, hogy a tulajdonnal nem rendelkező tömegek ugyanolyan veszélyt jelenthetnek a békés polgári létre, mint a nemzetiségi ellentétek. Sőt, ironizálnak is az új eszmék felett, Communisten-Examen címmel az alábbi mondókát jelenteti meg az egyik temesvári lap: „Wo fängt die echte Freiheit an?/Wo Jeder nimmt, was er kriegen kann!/Und wo erst findet Gleichheit statt?/Wenn endlich keiner mehr was hat!“.34

Feldinger/Földényi legfigyelemreméltóbb verse ebben a Vierzehnte Apriban a Republikanisches Trinklied című, de hasonló szellemben íródtak a Dem Gott der Freibeit hat es

31 Der vierzehnte April. Nr. 16. Pest, 19. Juni. 60. „A szerbek elleni első harc biztosan nem elnyomó jellegú volt, mert Magyarország fiai saját indíttatásból soha nem nyomtak el egyetlen népet sem, és nem is fogna soha. Biztosan a sátáni metternichi terv valósult itt meg, mely szerint Magyarország különböző nyelvű lakóit egymás ellen kell lázítani és polgárháborúba taszítani őket, hogy aztán erőik és szabadságuk elpusztításával könnyebben uralkodni, jobban mondva zsarnokoskodni lehessen az elesetteken." (ford. B. A.)

32 Der vierzehnte April. Nr. 1. Pest, 1. Juni 1849. „Fölöslegesnek tartjuk kifejezni gondolatainkat a legújabb társadalmi agyszüleményekről, tekintettel a kommunizmussal való gyanúsításokra és arra, hogy a monarchisták ezzel mocskolják be a republikanizmus tiszta zászlaját, néhány szót mégis szólunk róla. Magyarországra nézve nevetségesebbnek tartjuk a kommunizmus bevezetésének elképzelését, mint a kommunizmustól való félelmet magát." (ford. B. A.)

33 Táncsics ápr. 2-tól dec. 29-ig megjelenő lapja megosztotta az olvasótábort, a nincstelenek örömmel fogadták, hogy valaki az ô érdeküket is képviseli, ám maga Kossuth is arra figyelmeztette Táncsicsot, hogy lapjával árt a szabadságharc ügyének. Meghaladja jelen dolgozat kereteit, ám kétségkívül érdemes lenne megvizsgálni, hogy hasonló elutasításban részesült-e a kommunizmus ideológiája a magyar lapokban is, mint az említett németekben, illetve melyek voltak az állomásai a Kommunista Kiáltvány korai recepciójának.

34 Temesvárer Wochenblatt für nützliche Unterhaltung und heimatliche Interesse. 14. Okt. 1848. 344. „Hol a szabadság hona?/Ott, hol lop sógor, koma!/S mikor egyenlők, soha?/De, ha minden ellopva!" (ford. B. A.) 
so gefallen..., vagy az An Damjanich címü versek is. Ezekben a szövegekben Feldinger már annak a képviseleti beszédmódnak az elemeit használja, amely később meghatározó lesz az Euphrosine címú lapban, vagyis retorikailag létrehozza a származási alapú összetartozást a közös múlt, a közös hősök, a közös sors elfogadásával, például a következő szószerkezetekben: unserem Kossuth, Das wir von Habsburgs Druck befreit, Wenn Tyrannei uns wild bestrümet. Ebben a konstellációban a közös nyelven alapuló hagyományközösségi nemzetparadigma elveszti értelmezhetőségét, mert némiképpen ahhoz a Bécsből irányított és kudarcba fulladt állampatrióta-programhoz közelít, mely szerint a nemzet-képviseleti énformálás retorikailag történik: a közös területen lakó népek sorsa is közös, ebben a konkrét helyzetben a zsarnokságként felfogott monarchikus rendszer megdöntése a cél. Ezért ebben a negyvennyolcas hazafias költészet hagyományait folytató versben egy olyan narratívát hoz létre német nyelven, amely a konkrét hősök tetteiből eredezteti a szabadság kivívását (a vers tkp. pohárköszöntő Kossuth és Görgey tetteire), ugyanakkor a szabadság kivívásában az egyénileg is hősként tételeződő huszárok játsszák a legfőbb szerepet. A huszárok jellemzője pedig nem a nyelvi alapú elkülönülés, hanem az önzetlen áldozatkészség, az anyagi problémákat ignoráló odaadás és a szabad haza szeretetének határtalansága. ${ }^{35}$

Ugyanezt a programot folytatja az 1851-ben Temesváron megindított Euphrosine címü lap, amely közel 10 hónapig jelenhetett meg, és német nyelven folytathatta a szabadságharcos beszédmódot. Nyilvánvaló, hogy finomítani kellett a hangnemen, a rejtőzködésre utal a lap alcíme is: Erheiterungsblätter für Kunst, Literatur und gemeinnützige Unterhaltung (Mulattató múvészeti, irodalmi és közérdekű szórakoztató lapok). Kánya Emília a német nyelvűséget a temesvári magyar nyelvű közeg hiányával indokolta, de feltehető, hogy Feldinger mégis otthonosabban mozgott ebben a nyelvben. „Még 1851-ben, januárban támadt fel férjemben az ötlet egy kis újság, egy német (!) újság kiadására. Magyarul abban az időben nem lehetett volna Temesvárt lapot kiadni, nem akadt volna közönsége, egypár barátunkat kivéve. (...) Csak a katona ment akkor emberszámba és a német beamter. Mi, magyarok majdnem csak titokban lézengtünk, látogattuk egymást, közöltük egymással a külföldről beszivárgott jó híreket, sőt olykor még a lánglelkű Petőfink életben maradásán sem kételkedtünk, és elhittük gyönge óráinkban még azt a mesét is, hogy valamelyik félismerősünk a múlt télen találkozott is vele egy Krassó megyei rengeteg erdőben, majdnem vadállattá elzüllve, gyökereket rágcsálva. A németekkel látszólagosan mégis kellett érintkeznünk, amint azt az öregúr is szükségesnek tartotta”. ${ }^{36}$ A lapban ${ }^{37}$ Feldinger csupán nevének német alakját használja, így is meglepő, hogy folyamatosan híreket jelentethetett meg a 48-as emigránsokról (ami a magyar lapokban tilos volt), az első lapszámban közölhette Petőfi életrajzát és a korábbi hazafias versekre em-

35 „Das dritte Glas gilt den Huszáren,/Ihr Ruhm durchbringt die weite Welt,/Noch sind sie tapfer wie sie waren,/Ein jeder Huszár ist ein Held./Dem Honvéd Jedem unserer Schaaren,/Ein Hoch! denn Keiner kämpft um Geld,/Ein jeder hat der Freiheit sich geweiht,/Und Gott der Freiheit selbst kämpft mit, den Streit.“

36 KÁNYA Emília: i. m. 134.

37 Euphrosine. Erheiterungsblätter für Kunst, Literatur und gemeinnützige Unterhaltung. Temesvár, 1851. Árpilistól változik az alcím: Erheiterungsblätter für gemeinnützige Unterbaltung, Vaterlandskunde, geistiges und geselliges Leben. Eddigi legalaposabb bemutatása: Walter EngeL: Deutsche Literatur im Banat (1830-1939). Heidelberg. 1982. 55-78; FABó Irma: Az „Euphrosine”, negyvennyolc és Petöfi. Magyar Könyvszemle. 1974/1-2.149-155. 
lékeztető költeményeket jelentethett meg. Feldinger bevallása szerint a lapot annak hazafias jellege miatt tiltották be, a felesége viszont arról tudósít, hogy a kezdetektôl anyagi gondokkal küzdöttek, és végül emiatt függesztették fel a megjelentetését ${ }^{38}$. A nemzetiségi problémákat továbbra is mellőző kiadvány jellegét a szakirodalom gyakran a bánsági többnyelvűséggel, a kultúrák iránti toleranciával magyarázza ${ }^{39}$, ám ennek némiképp ellentmond, hogy például Feldinger kortársa és Klapka György egykori iskolatársa, Karl Wilhelm von Martini, miután kilép a honvédek sorából és 1848-ban itáliai utazásra indul, felismeri, hogy amennyiben a különböző nemzetiségek nem fognak össze, a szabadságharc elkerülhetetlenül bukásra van ítél$\mathrm{ve}^{40}$. Több levelében is kifejti, hogy a magyar nemzetiségi törekvések nem veszik figyelembe a nem magyar anyanyelvüek érdekeit, ezért belső meghasonlás következhet be. Feldinger a problémákat nem látja, olyannyira nem, hogy a cseh-morva származású, német anyanyelvű családból származó Klapkát, akinek apja ráadásul Temesvár polgármestere volt, a következőképpen jellemzi: „Klapka besitzt eine auffalend interessante Persönlichkeit und ein feines Außeres. Seine nicht hohe, aber höchst elegante Figur, sein regelmäßig längliches Gesicht mit schwarzem Schnur- und Knebelbart und feurigen dunklen Augen, seine braune Gesichtsfarbe verräth im ersten Augenblick das Kind der magyarischen Race“. ${ }^{41}$ A Petőfiéletrajzban úgy tűnik, mintha a magyar nemzet nagy költőjéről írna, de nyilván számolnia kellett a cenzúrával annak ellenére is, hogy az újonnan alakult Szerb Vajdaság és Temesi Bánság területén az enyhébb volt, mint Magyarországon. Az első számban megjelenő életrajz címe: Denkwürdigkeiten des 1. Jänner és bevezetője a január elsején született jeles emberek életrajzát ígéri, ám a német népköltő Bürger és Petőfi adatain kívül másokkal nem foglalkozik. Azonban Bürger emlegetése és rövid jellemzése is csak álca, hiszen az igazi népköltő attribútumait nem benne, hanem Petőfiben fedezi fel. Tisztában van azzal a ténnyel, hogy 1851ben Petőfiről dicshimnuszt zengeni, ezáltal a költőt a Habsburg-ellenállás eszközéül felhasználni, nem veszélytelen cselekedet. Annak ellenére, hogy az életrajzi adatok felsorolásánál és a költészete rövid értelmezésében próbál tárgyilagos maradni, mégsem kerülheti el Petőfi 48as szerepvállalásának, 49-es eltűnésének és Szendrey Júlia újbóli férjhez menésének vázolását, ezáltal pedig a későbbi Petőfi-kultusz legfontosabb elemeinek meghatározását. Írása utolsó soraiban elzárkózik a kultuszteremtés aktusaitól azáltal, hogy Petőfi költői érdemeit emeli ki, ugyanakkor írását az utólagos cenzúrától is óvja: „Als Kunstfreunde glaubten wir diese Notizen dem Andenken Petöfis hier widmen zu dürfen, indem die Kritik immer nur den Dichter an und für sich ins Auge fassen, und sich durch den moralischen und politischen Charakter des Individuums weder bestechen noch verstimmen lassen darf". ${ }^{42}$ A tárgyilagosság és az ideológiai függetlenség látszatának fenntartására utal az a tény is, hogy az életrajzi

38 Kánya Emília: i. m. 135.

39 Dieter Kessler: i. m., Heinz Stănescu: i. m.

40 Dieter Kessler: Der Erdfleck zwischen Donau, Theiss und Marosch. Notizen zu Karl Wilhelm von Martini (1821-1885). Verlag Südostdeutsches Kulturwerk. München, 1987.

41 Euphrosine. 1851. febr. 2. 37. „Klapka érdekes természettel és finom külsővel rendelkezett. Nem túl magas, de a lehető legelegánsabb alakja, szabályos, keskeny arca, bajusza és kecskeszakálla, sötét, tüzes szeme és barnás arcszíne első pillantásra elárulják hogy a magyar faj gyermeke.” (ford. B. A.)

42 Euphrosine, 1851/1. „Mint a múvészet barátai, feljogosítva éreztük magunkat e jegyzettel adózni Petőfi emlékének. Mert a kritikának csakis a költőt kell szem előtt tartania, nem szabad az individuum erkölcsi vagy politikai jelleme által megvesztegettetnie vagy elkedvetleníttetnie magát." (A 
sorozatot a következő számban Schlick tábornokéval folytatja, hogy később Görgey igen érdekes pályaképével, majd pedig Klapka György és a hősként ünnepelt Zrínyi Miklós nemzeti értékeit is olvasói elé tárja. Kultuszteremtő tevékenységnek pedig újabb bizonyítéka, hogy a még életben levő Klapka születési dátumában (azt tévesen márciusban határozva meg) determinálva látja Klapka későbbi szerepvállalását a szabadságharcban. ${ }^{43}$

Az Euphrosine címú lapban nevesebb szerzők mellett gyakran maga Feldinger is jelentkezik versekkel vagy humoreszkekkel. Ez utóbbiakat a mai olvasó gyakran erőltetettnek érzheti, és nehezen értelmezhető (bár nyilván emocionálisan magyarázható) a negyvennyolcas beszédmód túlfeszítése, a korábbi retorika adaptálása ahhoz az elkeseredett időszakhoz, amelyben a lap megjelenik ${ }^{44}$. Ennek egyik legjobb példája a Brudersinn címú, 1851 februárjában megjelenő vers, melyben a szabadságharcos összefogás és testvériség szelleménél fontosabb, jelentősebb és maradandóbb lesz a szerencsétlenségben, a mostoha körülmények között tanúsított egymás melletti helytállás. A békeidők testvéri szeretete ugyanis könnyen szertefoszlik, de akik a fájdalomban válnak eggyé, soha többé nem szakíthatók el egymástól: „Denn, die im Glücke sich gefunden, hat oft ein Wölkchen schon zerstreut,/Doch trotzen, die Ein Schmerz verbunden, vereint den Strümen jeder Zeit“. ${ }^{45}$

Annak ellenére, hogy Feldinger/Földényi visszonylag hosszú életet élt, az általa és kortársai által dédelgetett köztársasági tervek megvalósulását (bár nyilván egészen más formában, mint ahogyan azt ők elképzelték) nem érhette meg. Életének Pesten töltött idejéről nem sokat tudunk, a magyar nyelvű alkotói periódusból nem ismerünk jelentős alkotásokat. Életpályája talán pont amiatt lehet tanulságos, hogy a hatalmas arányú magyarrá vált német polgárság egyik tagjaként nem feltétlenül a magyar kultúrát gazdagította műveivel, hanem a nyelvében német olvasóközönség felé közvetítette sikeresen a magyar republikánus törekvéseket, a nyelvi elkülönülést mellőző polgári demokrácia megteremtésének igényét.

fordítás Izsáк Lászlótól származik: Izsáк László: Petôfi első biográfusa és a temesvári Euphrosine. Korunk. 1973/1.143.)

43 Euphrosine. 1851. febr. 2.37.

44 Az egyik legnehezebben érthető és értelmezhető szöveg az 1851. február 15-én megjelenő An die Wortrei(c)hen címú vers. Az értelmezést nehezíti, hogy nehezen lehet feloldani a személyes névmással jelölt entitásokat, nem tudjuk ki a te, ki az ő, ki a versbeszélő. Erre a szövegre egyetlen Feldingerről szóló írásban sem találtam utalásokat. Megkockáztatnám, hogy az identitásválságnak egy olyan szintjére jutott el, amikor végérvényesen elfordul a német nyelvű közösségtől és a magyar nemzettel vállal azonosságot.

45 Euphrosine. 1851. febr. 26.65. 


\section{IDENTITY ELEMENTS IN A 19TH CENTURY CAREER: GOTTFRIED FELDINGER/FÖLDÉNYI FRIGYES}

\section{Keywords: bilingualism, personal and national identity, assimilation, periodical of Romantic}

The identity problems of the Banat Germans are supplemented by the life-story of Gottfried Feldinger (1819-1900), lawyer, newspaper editor, composer from Temesvár. Working at Temesvár till the mid-1800s, in the early 60s he moved to Budapest and Magyarized his name to Földényi. With his first wife, Kánya Emília, issued a German language newspaper entitled Euphrosine in 1851, which ceased after a short operation. An interesting contribution of the search for identity is that Feldinger writes the first biography of Petőfi Sándor. In this paper I'm searching for the answer to how the local Banat and Hungarian indentity components appear in his writings.

\section{ELEMENTE IDENTITARE ÎN A DOUA JUMĂTATE A SEC. AL 19-LEA: GOTTFRIED FELDINGER/FÖLDÉNYI FRIGYES}

\section{Cuvinte-cheie: bilingvism, identitate individuală şi națională, asimilire, reviste pasoptiste}

Problemele de identitate ale germanilor din Banat sunt completate de biografia lui Gottfried Feldinger (1819-1900), avocat, redactor de ziar, compozitor din Timișoara. A lucrat la Timișoara până la mijlocul anilor 1800, la începutul anilor 60 s-a mutat la Budapesta și a preluat numele maghiar Földényi. Împreună cu soția sa, Kánya Emília, au publicat revista germană Euphrosine în 1851, care a încetat după o scurtă activitate. Un aport interesant în cercetarea identității constituie faptul că Feldinger a scris prima biografie a lui Petófi Sándor. În această lucrare analizez cum apar componentele de identitate locală bănățeană și maghiară în scrierile lui. 